\title{
Development of Cardiac Troponin I Electrochemical Impedance Immunosensor
}

\author{
Meng Xiong , Xihua Wang, Yanan Kong and Bin Han \\ Zhongda Hospital, Southeast University, Nanjing, Jiangsu, 210000, P. R. China \\ *E-mail: mengxiong_nanjing@yahoo.com
}

doi: $10.20964 / 2017.05 .22$

Received: 29 January 2017 / Accepted: 8 March 2017 / Published: 12 April 2017

\begin{abstract}
It is well known that acute myocardial infarction (AMI), a type of heart attack, is a primary cause of sudden death that has high potential to lead to nonreversing damage or necrosis of myocardial tissues. In this easy, we focused on the biosynthesis of Ag nanoparticles with the employment of green algae Stoechospermum marginatum as a reductant. The whole course of synthesis was fast in which the development of $\mathrm{Ag}$ nanoparticles was accomplished less than 1 hour after the chemical reaction between Ag salt and algal extract. After this, the AgNPs were utilized for the formation of electrochemical impedance cardiac troponin I immuno-transducer.
\end{abstract}

Keywords: Electrochemistry; Immunosensor; cTnl; Acute myocardial infarction; Diagnosis

\section{$\underline{\text { FULL TEXT }}$}

(C) 2017 The Authors. Published by ESG (www.electrochemsci.org). This article is an open access article distributed under the terms and conditions of the Creative Commons Attribution license (http://creativecommons.org/licenses/by/4.0/). 